\title{
Reflexões da história do patriarcado para esses tempos de pós-verdade ${ }^{+*}$
}

Marinês Domingues Cordeiro ${ }^{1}$

Departamento de Física - Universidade Federal de Santa Catarina Florianópolis - SC

\section{Resumo}

Neste ensaio, apresento a concepção de ciência como conhecimento social, que compreende que sua lógica reside justamente em sua característica social. Sem a crítica intersubjetiva, não haveria como identificar e minorar os efeitos de valores contextuais que acabam por invadir quase todas as áreas da ciência, desde os dados, até as hipóteses. Parto, então, para um diálogo entre os pilares da política sexual - biologia, ideologia, família, força, educação, religião, psicologia - com a robusta hipótese histórica do patriarcado que compreende que ele é anterior à patrilocalidade e à propriedade privada. A ideia de um patriarcado politico e histórico joga luz a diversas questões que vivemos nestes tempos de pós-verdade, como, por exemplo, a estruturação e os objetivos políticos das guerras de narrativas. Preferindo o termo objetividade ao termo verdade, faço considerações que a ciência e a educação têm papel dual nas guerras de narrativas da atualidade, assim como tiveram na política sexual e proponho que a estrutura tradicional e ainda frequente do ensino de ciências, em sua forma bancária e autoritária, talvez seja uma das razões pelas quais as pessoas tenham preferências pelas atuais bolhas de distorção dos fatos.

Palavras-chave: Patriarcado; Intersubjetividade; Subdeterminação; Valores Contextuais; Guerra de Narrativas.

\footnotetext{
${ }^{*}$ Considerations from the history of patriarchy for post-truth times

* Recebido: junho de 2020.

Aceito: setembro de 2020.

1 E-mail: marinesdc@outlook.com
} 


\begin{abstract}
In this essay, I present science as social knowledge, a conception to which the logic dimension of science lies precisely in its social character. Without intersubjective critique, there would be no way to identify and mitigate the effects of those contextual values that end up invading almost all areas of science, from data to hypotheses. I further associate the instances of sexual politics - biology, ideology, family, force, education, religion, psychology - with the robust historical hypothesis of patriarchy as prior to patrilocality and private property. The idea of a political and historical patriarchy sheds light on several issues we deal with in these post-truth times, such as narrative wars, their structure, and political objectives. Preferring the term objectivity over the term truth, I consider that science and education plays a dual role in today's narrative wars, just as it does in sexual politics, and propose that the traditional authoritarian structure of science education could be one of the reasons why people have inclinations towards the current fact-distorting bubbles.
\end{abstract}

Keywords: Patriarchy; Intersubjectivity; Underdetermination; Contextual Values, Narrative Wars.

\title{
I. Introdução
}

Talvez a melhor expressão para qualificar o momento histórico de aprofundamento da pós-verdade seja guerra de narrativas. Não parece exagero qualificar como guerra, porquanto tais disputas se enraízam cada vez mais no campo político tradicional. Entre os discursos dos lados que rivalizam, há baixas, acirramento de diferenças, sentimentos de alienação e radicalização de perspectivas. Também é eloquente a segunda parte da expressão - as disputas, afinal, são travadas entre narrativas, modos específicos de interpretar e representar o mundo. Apesar de a história da humanidade ser cheia de conflitos de narrativas, a massificação do acesso aos variados meios de comunicação, sobretudo as redes sociais, certamente cravou a analogia bélica que predicamenta a expressão, na segunda década do século XXI.

Seguramente, o termo pós-verdade leva cientistas, educadores em ciências e filósofos ${ }^{2}$ a recorrer às filosofias e aos episódios de história da ciência em que o termo

\footnotetext{
${ }^{2}$ Apesar de compreender que a linguagem, especialmente as línguas latinas, tem o efeito de patriarcal de masculinizar termos neutros, acho que o recurso de flexionar em ambos os gêneros deixa a leitura e a escrita mais difíceis. $\mathrm{O}$ recurso de neutralizar com usos de $\mathrm{x}$ ou e nas palavras generizadas também vai totalmente contra minha concepção de escrita, por não ser inclusivo para quem precisa de dispositivos de leitura e ir contra a norma culta. Como meu objetivo neste trabalho é o de mostrar que as mulheres são personagens históricos
} 
verdade possa ser escrutinado. Dessa forma, busca-se entender a validade do termo, dentro das compreensões históricas e filosóficas do que é conhecer cientificamente. Contudo, para Lúcia Santaella (2018), a pós-verdade não deve ser verdadeira para as ciências, assim como não é para a própria filosofia ou para a arte. O que a socióloga quer dizer com veracidade da pós-verdade é ela ser um fenômeno fatual nesses campos, algo de que discorda. Para ela, em ciências, filosofia e artes, as percepções de verdade podem ser múltiplas ou históricas, mas jamais são secundarizadas ou aliciadas. É dentro das relações de poder entre comunicação e política que o fenômeno existe, é palpável e precisa de tratamento acadêmico, pois é nas narrativas políticas que a verdade vem sendo secundarizada ou ignorada, em nome de disputas e até guerras de narrativas.

Mesmo que aceitemos essa definição - a de que o fenômeno de pós-verdade se constitui como tal na dimensão política-comunicação - não se pode escapar do fato de que política e ciência (assim como comunicação e ciência) com frequência se associam. As narrativas políticas podem envolver, portanto, pseudociências e negacionismos, sobretudo aquelas sob ideologia fascista. Fazem-no muitas vezes pautadas no fato de que a filosofia da ciência discute perenemente questões relativas à racionalidade, objetividade, realismo e verdade. Usa-se, assim, uma discussão que, dentro da filosofia da ciência e da própria ciência, se mostra muito profícua, como argumento para negar a própria ciência ou erigir justificativas para conhecimentos não respaldados pela comunidade científica. Os exemplos batidos dos terraplanistas, defensores da homeopatia e do movimento anti-vacina, assim como a nova discussão acerca da cloroquina como panaceia contra a pandemia de Covid-19, mostram claramente as inter-relações entre ciências, política e comunicação. Assim, mesmo que a pósverdade não seja um fenômeno em si próprio dentro da ciência e da filosofia da ciência, as discussões desses campos vêm sendo cooptadas para o campo político (tradicional) - não raramente com objetivos antidemocráticos. É uma distorção de narrativa científica - que tem seus modos de produção, autocorreção e crítica - para o fomento de uma guerra de narrativas mais ampla, que apesar de metodologicamente pobre, parece ser muito eficaz em hackear determinadas inclinações psicológicas e a própria fisiologia humanas.

Até agora, quis construir o argumento inicial de que o tema da pós-verdade e da guerra de narrativas transita em dois níveis - o da filosofia da ciência e o da sociologia política. Para partir em busca da resposta à provocação do título deste ensaio - que reflexões o conhecimento da história do patriarcado pode trazer a esses tempos de pós-verdade proponho um novo nível de entrelaçamento entre sociologia e filosofia. Porque a história do patriarcado vem sendo contada especialmente nos últimos três séculos, e mais preponderantemente a partir de perspectivas bastante androcêntricas de poder, e porque ela envolve a análise de evidências e a crítica das interpretações que essas evidências suscitam,

ativos no mundo, peço que não se deixe obscurecer esta mensagem pela linguagem, fator cuja mudança está parcialmente fora do meu controle. 
ela pode nos mostrar, entre outras coisas, que disputas de narrativas não são coisas novas, que elas servem a intenções de poder, que elas envolvem a subdeterminação das teorias pelas evidências e que, tristemente, narrativas pseudocientíficas podem silenciar as mais precisas e coerentes narrativas, mesmo no ápice da vivacidade de movimentos, como o feminista da atualidade. E mais importante: porque o patriarcado é o sistema político mais antigo da humanidade. Sua história tem todos os ingredientes necessários para se dar perspectiva ao fenômeno da pós-verdade contemporâneo - ciência, pseudociência, comunicação, estruturas de poder, silenciamento, omissão.

Para a construção de um argumento teórico sobre os paralelos entre as disputas de narrativas travadas para distintos (mas consanguíneos) sistemas políticos, estruturo este ensaio como um trajeto, dentro de uma visão ampla de política, que passa pela filosofia da ciência como conhecimento social, de Helen Longino (1990), culminando na análise das bases do patriarcado e suas origens históricas, fazendo dialogar principalmente a concepção de política sexual, de Kate Millett (2000), e a criação do patriarcado, de Gerda Lerner (1986). É por entender as lições filosóficas da história que pretendo apresentá-la, na defesa de que a educação científica deve mudar radicalmente sua abordagem para o estímulo da crítica e do pensamento divergente, pois está na frente de batalha da guerra de narrativas.

\section{Ciência como conhecimento social}

No senso comum e em variadas áreas de conhecimento, é corriqueiro associar verdade a alguma espécie de realismo. Fatos e notícias, por exemplo, são considerados verdade porque são uma representação evidente e direta da realidade. Na filosofia da ciência, entretanto, a palavra verdade não necessariamente demandará comprometimento com o realismo científico. De fato, o termo verdade pode ter significados em variados níveis epistemológicos, e mais importante que uma incursão em questões ontológicas, demanda uma pormenorização do objetivo da ciência e a maneira como a comunidade científica se propõe a alcançá-lo. Coerentemente, para um realista, o objetivo maior da ciência seria a verdade, no sentido de uma aproximação com a realidade. Para um antirrealista, logicamente, esse não poderia estar mais longe do objetivo. Mas mesmo para esse grupo de filósofos, que em geral compartilha a concepção de que a ciência almeja a criação de um corpo de conhecimentos com sólida capacidade explicativa, nem sempre verdade é considerada uma concepção inaceitável. Muitos podem tratá-la como um valor, uma espécie de característica do conhecimento prezado pelos cientistas, por eles ponderado nos mais diversos níveis de suas pesquisas e que tem mais a ver com precisão, fidedignidade (LONGINO, 1990).

São duas maneiras de se ver a verdade - como objetivo maior da ciência, ou como valor cognitivo nas práticas científicas. Logicamente, ambas atribuem diferentes significados ao termo: correspondência ou valor. Seria fundamental uma incursão mais profunda na filosofia da ciência para que esse artigo pudesse promover uma leitura bem guiada dentro da 
polissemia do conceito de verdade. Ademais, o senso comum, que atrela fortemente verdade a realidade, acaba enfatizando apenas este significado da concepção para os leitores. Proponho então uma troca. Neste trabalho, darei preferência ao termo objetividade, justamente por seu sentido oriundo do senso comum ser menos enrijecido. Naturalmente, também buscarei desvinculá-lo da noção de correspondência, porque não busco aqui um compromisso ontológico radical com a realidade, mas também porque pretendo apresentar uma tese filosófica bastante profícua para as áreas que tento articular neste trabalho, quais sejam, política sexual, guerra de narrativas e educação científica. É a defesa da ciência como conhecimento social, tese da filósofa estadunidense Longino (1990), que procura mostrar que a lógica da ciência reside especificamente nos seus mecanismos sociológicos.

À semelhança do que fizeram vários pensadores posteriores a Kuhn, como Laudan (1984), Hacking (2012) e mesmo o próprio Kuhn (2009), por exemplo, buscando reconstruir sobre o que entendiam ser a terra arrasada deixada por A Estrutura das Revoluções Científicas (KUHN, 2006), Longino compreende que uma lacuna filosófica se formou entre abordagens lógicas, mas historicamente fracas, e abordagens históricas, mas insatisfatórias logicamente. Enquanto Laudan (1984) se ocupou da racionalidade da ciência, e Hacking (2012) do realismo de entidades, Longino foca na objetividade da ciência (assim como Kuhn o fez, embora insuficiente e quase apologeticamente $\left.{ }^{3}\right)$.

Naturalmente, Longino (1990) não se propõe a salvar a perspectiva positivista de objetividade atrelada a métodos. Também não pretende uma incursão na ideia realista de objetividade como aspecto da correspondência. Para reconstruir a concepção de objetividade, propõe que se mude o foco analítico da ciência: não mais focar nos métodos executados por um determinado cientista, mas sim na ciência como uma prática intersubjetiva. Para ela, a falha dos filósofos de ambas as inclinações residia na tentativa de compreender a ciência e seu sucesso a partir de análises individualistas. Positivistas, por exemplo, focam nos métodos e nas justificações desenvolvidas por um cientista; os holistas - como ela classifica Kuhn apesar de garantir a coletividade da ciência, veem-na como uma prática acrítica, como uma atividade de manada.

Para a filósofa, não basta que ciência seja feita em coletividade, mas que seja intersubjetiva, ou seja, é essencial que o conhecimento circule entre variados membros devidamente iniciados da comunidade. Revistas, conferências e congressos são claros indícios de que não há ciência feita sem coletividade. Mas, para que servem esses espaços? Evidentemente, não são para a mera apresentação de pesquisas e resultados. Com efeito, são âmbitos essenciais para o fomento da crítica entre os pares, a crítica intersubjetiva. Assim, é possível compreender o que Longino (1990) entende por ciência como prática intersubjetiva:

3 Em seu trabalho, Kuhn (2009) busca amenizar as contundentes críticas recebidas por A Estrutura das Revoluções Científicas, atribuindo a objetividade à capacidade da comunidade de ponderar valores cognitivos como exatidão, simplicidade, coerência, alcance e fertilidade, dando uma nova nuance ao fenômeno da incomensurabilidade. 
é mais profícuo examinar a objetividade da ciência ao olhar para sua característica social do que ao individualizar sua análise.

Sua característica social faz com que a ciência prospere com a crítica, e não com a aquiescência. Caso o fosse, nada garantiria o sucesso da ciência, sobretudo em prover quadros explicativos bastante abrangentes, como vem fazendo. Em suas palavras:

\begin{abstract}
De um ponto de vista lógico, se o conhecimento científico fosse entendido como a simples soma de produtos finalizados de atividades individuais, então não apenas seria impossivel bloquear ou mitigar as influências de preferências subjetivas, mas o próprio conhecimento seria uma miscelânea de teorias divertidamente inconsistentes. Somente se os produtos da investigação forem compreendidos como formados pelo tipo de discussão crítica que é possivel entre uma pluralidade de indivíduos acerca de um fenômeno comumente acessivel, conseguimos notar como eles podem ser considerados como conhecimento, e não como opinião. (LONGINO, 1990, p. 74, tradução nossa).
\end{abstract}

Ao compreender a objetividade como uma função do grau de circulação e exposição à crítica por que passa determinada hipótese, Longino (1990) ressalta que a lógica é subjacente à ciência como prática social, por ser a única maneira de mitigar valores subjetivos ou contextuais. Ela nota que, no trabalho de determinado cientista ou grupo, preferências subjetivas podem adentrar quaisquer âmbitos da construção de conhecimento. Podem penetrar as práticas, os códigos de conduta essenciais compartilhados pelos cientistas - como a necessidade de submissão à crítica intersubjetiva, ou a descrição detalhada de metodologias, dados e evidências. Também os próprios dados podem ser determinados por valores contextuais, assim como as questões escolhidas e ignoradas para investigação. As suposições específicas que guiam as interpretações erigidas pelos cientistas, assim como as suposições globais, que provêm o pano de fundo em relação ao qual veem a totalidade de uma pesquisa, também não estão imunes à interferência de preferências subjetivas. Fica claro, portanto, o papel fundamental que desempenha a crítica intersubjetiva, que apenas a coletividade pode exercer, sobre uma hipótese aventada.

Ao submeter uma hipótese ao escrutínio dos pares, na forma de publicação de artigos ou de apresentação em congressos, o trabalho pode ser criticado em termos conceituais ou evidenciais. As críticas evidenciais estariam atreladas a questões experimentais e observacionais. Já as críticas conceituais problematizariam questões de natureza teórica ou metateórica.

A filósofa, aliás, estende as diferenciações às possíveis qualidades de críticas conceituais - o tipo que ela entende fundamental para a questão da objetividade da ciência. Pode-se criticar a solidez conceitual de uma hipótese, algo como a ponderação da consistência da hipótese, traduzindo para os valores cognitivos defendidos por Kuhn (2009) ou Laudan (1984), por exemplo. Também é possível questionar a coerência externa da hipótese, isto é, seu diálogo com as teorias que formam o cânone em que a pesquisa se edifica. Por fim, há o 
tipo de crítica que questiona a relevância das evidências apresentadas para suportar a hipótese. Para Longino (1990), este terceiro tipo de crítica conceitual é essencial no problema da objetividade, porque é o que permite identificar e minorar os possíveis valores subjetivos que possam ter tido papel na construção da hipótese.

\begin{abstract}
Porque a relação entre hipótese e evidência é mediada por suposições de fundo que não podem ser submetidas a confirmação ou refutação empírica e que podem estar impregnadas com considerações metafisicas ou normativas, seria um equívoco identificar a objetividade dos métodos científicos apenas com seus aspectos empíricos. O processo que pode expor tais suposições é o que possibilita, mesmo que não possa garantir, a independência de vieses subjetivos, e portanto a objetividade (LONGINO, 1990, p. 75, tradução nossa).
\end{abstract}

Somente a característica social da ciência permite discernir e atenuar preferências subjetivas e construir um conhecimento robusto: "dados experimentais e hipóteses são transformadas por meio do conflito e integração de uma variedade de pontos de vista até o que é em última instância aceito como conhecimento científico" (LONGINO, 1990, p. 69, tradução nossa). Todavia, isso só acontece se as comunidades forem capazes de satisfazer quatro critérios essenciais. São necessários espaços reconhecidos para críticas, como conferências e periódicos; são imprescindíveis padrões compartilhados, aqueles valores cognitivos amplamente compreensíveis e valorizados por toda a comunidade, embora ponderáveis individualmente; faz-se fundamental a igualdade de autoridade intelectual, a máxima garantia de que a crítica e o debate se dê de modo horizontal, que a comunidade busque ouvir e considerar as críticas advindas de seus mais diversos membros; por fim, é essencial que a comunidade seja responsiva às críticas e às hipóteses, que esteja buscando um trabalho afinado em busca de um conhecimento que pode, em último nível, ser premiado e figurar em livros didáticos (mesmo que não haja nenhuma garantia que esse conhecimento tão consensual não possa mudar no futuro, como bem mostra a história da ciência).

Claramente, a objetividade para Longino (1990) não é um conceito determinado por uma realidade, mas o resultado de uma busca incessante pela mitigação de preferências subjetivas na ciência. Entretanto, nem sempre a composição da comunidade científica permite que valores contextuais sejam detectados. Muito facilmente, citamos lamentáveis e até criminosos episódios da ciência passada, como a eugenia, a ciência que tinha a superioridade de alguns grupos humanos como pressuposto global. Para episódios como tal, associa-se quase imediatamente o valor contextual ubíquo àquelas investigações à má ciência, consequentemente produzindo uma espécie de imagem neutra e imparcial do que seria a boa ciência. Contudo, sendo ela feita por pessoas que não socializam somente na comunidade científica, é difícil imaginar que valores contextuais não a adentrariam a "boa" ciência - seja lá o que isso possa significar -, e é o exato oposto do argumento de Longino. A própria concepção mecanicista da natureza, que vem transpassando as pesquisas físicas em suas mais variadas formas, é um pressuposto global oriundo de um momento histórico, que via o mundo 
como manipulável, e que persiste até hoje. Se o que resulta dela é boa ou má ciência, isso precisa ser ponderado pela comunidade científica e, também, pela sociedade.

Quando valores tipicamente contextuais se embrenham na ciência, sobrevivendo ao apuramento da crítica intersubjetiva, a filósofa diz que eles passam a desempenhar papel constitutivo na atividade. Isso ocorre, em geral, como fruto de um momento histórico, como no caso mecanicista, assim como em virtude da homogeneidade da ciência. A comunidade de pesquisadores que investigavam fenômenos sob os pressupostos eugênicos era, de fato, homogênea. Pouco se pode esperar da mitigação de valores contextuais em uma comunidade deste tipo. E se houvesse, digamos, pesquisadores negros, judeus e mulheres, trabalhando nas mais diversas linhas de investigação na época, desenvolvendo hipóteses sob o pressuposto da igualdade, criticando a relevância das evidências para as hipóteses eugênicas, eles seriam ouvidos? Não imediatamente, em virtude da falta de igualdade de autoridade intelectual ao qual o grupo dominante homogêneo os relegava. Mas, felizmente, esses grupos perseveraram. Entraram e se mantiveram na ciência e lutaram por espaço para mais dos seus. Variadas áreas da biologia, assim como de todas as ciências, vêm ganhando com isso, no sentido da ampliação do poder explicativo da ciência. Os estudos históricos e antropológicos sobre o patriarcado, também.

\section{Política Sexual: Desnudando as estruturas sociais do patriarcado}

Patriarcado é um termo ao qual, com as redes sociais e os levantes feministas, todos já nos acostumamos. A atual onda feminista usa a palavra com bastante frequência. O termo é tão reconhecido na atualidade que grandes varejeiras do vestuário produzem e vendem, com algum sucesso, camisetas com palavras de ordem antipatriarcais. Se for cooptado pelo capitalismo, sabemos que está circulando amplamente.

Apesar de usada abundantemente, a concepção não parece muito problematizada no senso comum, para além de caracterizar o estado social em que homens, como grupo, têm claros privilégios sobre as mulheres, como grupo ${ }^{4}$; a depender da perspectiva feminista defendida, os homens podem ser vistos de executores ativos do patriarcado a vítimas dele. Essas diferenças transparecem determinados valores contextuais compartilhados pelos diferentes grupos, e talvez fossem atenuadas com o endereçamento de perguntas sobre o que é efetivamente o patriarcado e de onde ele vem. Após décadas de ensino do tópico, afirma a historiadora Gerda Lerner (1986, p. 3, tradução nossa), atrelando fortemente o potencial de emancipação ideológica feminina ao conhecimento da história: "a história das mulheres muda suas [das estudantes] vidas. Mesmo a exposição de curta duração às experiências passadas das mulheres $[\ldots]$ tem o mais profundo efeito psicológico nas participantes".

\footnotetext{
${ }^{4}$ Não pretendo ignorar as questões de raça e classe na intersecionalidade das relações políticas. Voltarei ao tópico mais à frente. Em virtude da perspectiva histórica, manterei o foco, nesta seção, nas relações políticas entre os sexos.
} 
Não é como se ninguém nunca houvesse se perguntado sobre a origem da opressão das mulheres. De fato, no século XIX e no começo do século XX, algumas hipóteses foram propostas. Momento fortuito, é claro: depois da Revolução Industrial, e com a Primavera dos Povos, essas questões passaram a ser postas pelas próprias feministas, que começavam a se organizar, dando início ao que hoje chamamos de primeira onda feminista. Apesar de questionadas por mulheres, essas perguntas norteavam as pesquisas de homens, os controladores do conhecimento da época. Em consequência, poucos viam a questão lucidamente como opressão ou exploração, mas como condição ou destino. Entre as respostas mais conhecidas, no fim do século XIX temos a explicação materialista-histórica de Friedrich Engels, que associa a exploração das mulheres ao advento da propriedade privada; no começo do século XX, a hipótese psicanalítica de Sigmund Freud, que associa o patriarcado à compensação masculina dentro de um paradigma edipiano, e, um pouco depois, a antropologia estrutural de Lévi-Strauss (1982), que atribuía a condição feminina à patrilocalidade - o fato de que eram as mulheres que saíam da convivência de seus familiares consanguíneos para morar com homens de outras tribos - exigida pelo tabu do incesto. Essas hipóteses serão analisadas oportunamente.

Cabe aqui um adendo sobre a história do movimento feminista e sua estrutura comumente modelizada em ondas. A despeito de as reivindicações femininas terem tido espaço ao longo de toda história, e mesmo que seja possível citar nomes de mulheres que marcaram presença em espaços públicos, desempenhando funções em geral monopolizadas pelos homens (LERNER, 1986; 1993; SCHIEBINGER, 2001), o feminismo, como movimento social, político e, mais adiante, acadêmico, pode ser associado historicamente à Primavera dos Povos, em 1848 - no contexto ocidental (OFFEN, 2000). A partir daí, formaram-se grupos de mulheres que editavam periódicos, escreviam artigos, demandavam direitos ao sufrágio, à propriedade, à herança e ao divórcio, que começaram a crescer e a ganhar momento, assim como outros movimentos populares na mesma época. $\mathrm{O}$ movimento não foi coeso, mas um despertar pulverizado nas mulheres das variadas classes sociais, inclusive e importantemente entre mulheres escravizadas e abolicionistas (DAVIS, 1983; NYE, 1995). Há muitos que classificam esse primeiro levante das mulheres como elitista, ignorando que, nas mesmas décadas, mulheres negras demandavam o fim da escravidão e o direito a conviverem com seus familiares, mulheres operárias lutavam por salários equiparados aos dos homens e condições menos aviltantes de trabalho, e muitas delas também combatiam a exploração sexual e laboral infantil (DAVIS, 1983; OFFEN, 2000). Nestes termos, faz-se fundamental enfatizar as diferentes aviltações sofridas pelas mulheres; as mulheres escravizadas, aliás, são o retrato da luta perene contra as mais agudas violências patriarcais. Mesmo antes da instituição dos primeiros movimentos feministas, lideraram fugas e reagiram contra todo tipo de exploração, como mostram os registros históricos. A natureza dupla da exploração que sofreram - de raça e sexual - e suas bravas resistências a ela, 
demanda que seus papéis sejam considerados fundamentais na luta antipatriarcal do século XIX (DAVIS, 1983).

Na Física, uma onda é uma oscilação temporal, que é representada por uma crista e um vale. Não à toa, a analogia vem a calhar: na história do feminismo, cada crista ou intervalo histórico que envolveu ganhos sociais para mulheres foi seguida de vales, de contra-ataques por parte dos homens - e a academia desempenhou um papel fundamental nisso. As três teorias sobre a origem da exploração das mulheres mais reconhecidas foram aventadas ou no momento de ganhos feministas, na tentativa de trazer as mulheres para a crítica ao capital, caso da teoria marxista de Engels, ou no contra-ataque, como a psicanalítica e a antropológica estruturalista. Elas até tiveram alguma fertilidade no pensamento feminista, embora fique claro que retratavam a condição feminina como raiz de sua opressão e, principalmente no caso das duas últimas, seu destino inescapável, algo oposto a um pensamento verdadeiramente emancipatório.

O vale da primeira onda começa a se desenhar, portanto, já no fim do século XIX, mas não impede os avanços femininos, que ganham vários direitos neste ínterim. Não fossem as guerras, revoltas e revoluções daquelas décadas, talvez o contra-ataque às mulheres fosse maior. Mas, com os homens nos campos de batalha, restava a elas as atividades econômicas essenciais, gerando a necessidade de certa forma de "propaganda empoderadora" do trabalho feminino. Em 1945, entretanto, tudo muda. Com o fim da Segunda Grande Guerra, os homens voltam aos seus postos de trabalho e à esfera pública, mandando as mulheres de volta ao domínio domiciliar ${ }^{5}$. A essa altura, tinham conquistado os direitos ao voto, à propriedade e ao divórcio, embora houvesse grande dificuldade jurídica de se efetivar os dois últimos. Também estavam nas universidades, produzindo conhecimento (OFFEN, 2000). Mesmo com os ganhos, certas batalhas feministas continuavam (e continuam) sendo travadas, como por condições dignas de trabalho e salário, o direito à integridade física e contra o assédio sexual de mulheres e crianças. A violência doméstica e a dependência financeira marital, somadas à necessidade de controle de natalidade, também se constituíram como novos combustíveis para mais um crescente, uma nova crista, que, mais uma vez, emerge com outros movimentos sociais contraculturais a partir da década de 1960.

Assim, é na segunda onda feminista, mais precisamente em 1969, que, em sua tese de doutorado, Kate Millett enuncia claramente o patriarcado como um sistema político, amparado em uma série de pilares sociais para sua manutenção. Interessantemente, Millett era estudiosa de artes e literatura, e é analisando a misoginia da literatura anglófona e de esquerda do século $\mathrm{XX}$, especialmente no tocante a tópicos sexuais, que ela apresenta as primeiras evidências de sua tese: a de que a relação entre homens e mulheres é política. Sua tese transformada em livro é um texto fundamental do feminismo da época e vem influenciando fortemente pensadoras desde aquela década.

\footnotetext{
${ }^{5}$ Novamente, no ocidente. Certamente o destino foi diferente para as mulheres nas novas zonas de guerra, a Coréia, o Vietnã e o Oriente Médio.
} 
A propósito do título de sua tese, Millett (2000, p. 23, tradução nossa) defende que sexo é uma categoria com implicações políticas, e define política como "relações estruturadas em poder, arranjos pelos quais um grupo de pessoas é controlado por outro". Não apenas sexo, mas raça e classe também devem ser analisadas dentro de uma perspectiva política. "Pois é precisamente porque certos grupos não têm representatividade em numerosas estruturas reconhecidamente políticas, que sua posição tende a ser tão estável, sua opressão tão contínua" (ibid., p. 24, tradução nossa).

Todo sistema político necessita de pilares, implícitos e explícitos. Pode-se ver tal característica nos variados regimes amplamente conhecidos e estudados. Em geral, eles exigem a socialização para a aceitação, a construção de uma ideologia, a criação de mitos e religiões, a instituição da força (mesmo que em última instância - nenhum país se exime de ter polícia e forças armadas, afinal de contas), etc. O mesmo ocorre com o patriarcado: ele também tem seus fundamentos. Pilares como ideologia, sociologia, religião e força respaldam a política sexual, segundo Millett (2000), adicionados a biologia, classe, psicologia, economia e educação. São instâncias em que se erigem e inculcam a exclusividade do patriarcado na vida cotidiana, sua onipresença e onisciência. A partir das narrativas arquitetadas em cada um dos pilares, pode-se passar uma vida pensando que essa política é universal e, portanto, inescapável.

A tese de Millett (2000) busca suas evidências na análise literária e constrói seus argumentos em diálogo com outros pesquisadores da antropologia e da história de seu tempo. Assim, sua hipótese é um reflexo de sua conjuntura. Duas décadas depois, a historiadora Gerda Lerner (1986) busca, com análise de evidências paleoantropológicas da Idade da Pedra e históricas da Idade do Bronze até a Grécia Clássica, a proposição de uma hipótese que dê conta dos sinais do patriarcado como uma criação milenar, e não quase instantânea. De fato, sua conclusão é de que esse sistema precisou de cerca de 2500 anos para se consolidar. ${ }^{6}$ Explicações universalizantes sobre a dominação masculina, como a psicanalítica, que declara que para as mulheres a anatomia é destino, não resistem às evidências históricas. A historiadora ainda afirma que, se anatomia significou algo para a história das mulheres, foi na raiz do patriarcado, o que não significa, de maneira alguma, que deve ser o seu destino. Esta seção será uma conversa entre ambas as obras, já que o profundo estudo de Lerner (1986) circula pouco entre pesquisadoras feministas e é fortemente baseado na interação entre hipóteses, evidências e crítica intersubjetiva às pesquisas muitas vezes androcêntricas, permitindo lançar às histórias do patriarcado um olhar da ciência como conhecimento social. Mas ela é especialmente interessante por mostrar a fundação histórica dos pilares essenciais da política sexual enumerados por Millett (2000).

\footnotetext{
${ }^{6}$ Mesmo em sua amostragem - principalmente as civilizações mesopotâmicas - Lerner argumenta que não houve uma evolução temporal perfeitamente simultânea. Contudo, o patriarcado como ideologia culmina com o domínio simbólico criado pelas religiões patriarcais monoteístas, no primeiro milênio a.C.
} 
A biologia tem sido usada como justificativa para a supremacia masculina, ainda que de modo bastante superficial. Como pilar primeiro do patriarcado, defende-se que o homem seria dominante em virtude de sua maior envergadura e musculatura, além de produzir maior quantidade de testosterona e ter a necessidade instintiva de espalhar suas sementes ao máximo de fêmeas possível - o que supostamente o faria mais agressivo. Isso sustentaria a narrativa da humanidade caçadora-coletora (homens agressivos caçadores e mulheres vulneráveis e deferentes coletoras, no caso). Assim, o patriarcado seria um regime sustentado pela força física e pela agressividade; como a diferenciação sexual data de antes do homo sapiens, esse argumento biológico justifica seu presente e passado (MILLETT, 2000). A ciência por trás dessa justificação, apesar de ter suportado essa interpretação por muitos anos, é bastante falha e vem sendo disputada (LONGINO, 1990; LERNER, 1989; SAINI, 2017).

Para o argumento de que o patriarcado tem natureza primeva, as evidências paleoantropológicas são bastante enigmáticas. Em geral, os estudiosos analisam o problema a partir de objetos encontrados em sítios arqueológicos, e associam essas evidências às observações antropológicas de sociedades ainda existentes de caçadores-coletores. Assim, ficam muito longe de sustentar inequivocamente a narrativa do homem caçador e da mulher coletora e, sobretudo, o sistema de valores que dela surge, inclusive para justificar a divisão sexual de trabalho da atualidade. Como expõe Longino (1990), os instrumentos de pedra lascada, geralmente interpretados como ferramentas utilizadas pelos homens para a caça, podem ter sido criados e feitos essenciais tanto por fêmeas, quanto por machos. Esses instrumentos, afinal, não falam por si sós. Ademais, não há garantias de que as sociedades de caçadores-coletores remanescentes emulem precisamente as primitivas, já que, entre as atuais, existe uma ampla variedade de organizações sociais e distribuições de trabalho. Por conseguinte, os dados tipicamente usados pela paleoantropologia (e também pela antropologia) são influenciados por valores dos pesquisadores - inclusive pesquisadoras mulheres, que são fortes atuadoras na área desde a década de 1970 e que mudaram a tônica da interpretação desde então.

Cabe ressaltar que, considerando perfeitamente lícita a hipótese dos caçadorescoletores, são valores contextuais que acabam exaltando a figura do homem caçador em detrimento da mulher coletora. Compreendendo que, com o estado climático da época, com as mulheres tendo que maternar, amamentar e gestar, e com os homens fazendo grandes caças que poderiam levar dias, nada mais natural que a prática de caça de animais menores entre mulheres e crianças. Estudos das mais variadas sociedades caçadoras/coletoras mostram que as mulheres contribuem em média com sessenta por cento da alimentação de todos os membros - e as condições climáticas não são desfavoráveis como há dez milênios. Portanto, é difícil argumentar, sem o apelo a valores contextuais androcêntricos atuais, que a divisão sexual do trabalho primitiva, mesmo que existente, fosse o pilar de um sistema político de dominação tal qual é o patriarcado (LERNER, 1986). 
Mesmo que superado na academia, o argumento biológico e paleoantropológico da dominação masculina como produto do trabalho de caça e de seus atributos físicos ainda subsiste no senso comum. Ele é essencial para outro pilar do patriarcado - a família ${ }^{7}$. Deste argumento, afinal, segue a atual organização social da família, em que o homem preferivelmente trabalha e provê alimentação aos seus, enquanto a mulher preferivelmente fica em casa cuidando do conforto e dos filhos do homem. A família é o pilar sociológico do patriarcado. É na família que as pessoas são socializadas a performar os papéis esperados dentro da sociedade patriarcal. Ainda, grande parte do mundo atual vive sob a influência de religiões, mitos, filosofias e até ideologias patriarcais, como o fascismo, que se autorretratam semelhantemente à família. Não à toa, "famílias chefiadas por mulheres tendem a ser vistas como indesejáveis; o fenômeno é um traço da pobreza ou do azar" (MILLETT, 2000, p. 33).

Compreendendo as aviltações sofridas pelas mulheres dentro da estrutura familiar patriarcal e baseado nos estudos etnográficos do século XIX, Friedrich Engels defendeu, em 1884, que a subjugação das mulheres foi consequência da estruturação da propriedade privada e culminou na criação do estado. A narrativa materialista-histórica passa pela domesticação de animais, as trocas e acumulações que levaram à propriedade e a necessidade de garantir que os homens passassem suas propriedades aos herdeiros legítimos (consanguíneos), o que levou à "domesticação" também das mulheres, na forma de garantia desta última necessidade (ENGELS, 2000). Há uma série de problemas em seu argumento, como por exemplo, não conseguir explicar por que apenas os homens seriam os responsáveis pelas trocas de animais domesticados e de alimentos, por que se passou a valorizar a progênie ao ponto de reestruturar radicalmente a sociedade e as relações entre os sexos, além de parecer promover uma concepção bastante comunista das sociedades anteriores à propriedade privada e de emular valores vitorianos na sua visão de família primitiva (LERNER, 1986).

Como defendi, o argumento materialista-histórico foi fortuito, já que ocorreu juntamente ao primeiro levante das mulheres. A concepção central era de que a queda da propriedade privada levaria à queda do patriarcado, e logrou muitas adeptas entre as mulheres por, além disso, mostrar que a situação de subordinação feminina não é universal e atemporal. Contudo, as evidências históricas mostram que a instauração do patriarcado não se deu rapidamente, mas ao longo de milênios, germinando antes da propriedade privada (LERNER, 1986). Fosse esse o caso, teríamos visto o fim das relações de poderes entre homens e mulheres nas sociedades que experimentaram a organização comunista/socialista no século passado. Também, dentro dos movimentos socialistas, as demandas das mulheres eram tidas como secundárias às questões de classe e a relação entre os sexos estava longe de igualitária (NYE, 1995), do que se pode razoavelmente concluir que, mesmo dentro de um movimento revolucionário, a história das mulheres é nada mais que ferramenta de aliciamento.

\footnotetext{
${ }^{7}$ Etimologicamente, família vem do latim famullus, escravo doméstico. Assim, família seria o conjunto de propriedades de um homem, geralmente mulheres, filhos, escravos, terras e excedente de produção.
} 
Felizmente, as evidências históricas são mais resistentes que as antropológicas, embora ainda assim subdeterminem quaisquer hipóteses. Entretanto, com elas, é possível construir uma interpretação muito mais robusta das androcêntricas explicações de Engels ou Lévi-Strauss. Se Engels entendeu uma relação causal entre propriedade privada/estado e subordinação feminina, Lévi-Strauss (1982) encontrou no tabu do incesto a causa para o efeito da dominação masculina. Para o antropólogo, o impulso de evitar o incesto nasce da necessidade de manutenção da paz entre tribos. De seu argumento, segue a comoditização das mulheres, que eram trocadas pelos parentes homens - uma semente da relação de poder que viria a se estruturar. Como Lerner (1986) mostra, esse é mais um argumento monocausal que, assim como o marxista, inverte a relação entre causa e efeito. Sim, é fato que as capacidades sexuais e reprodutivas das mulheres passaram a ser reificadas e trocadas em determinado momento histórico, assim como se tornaram, mais adiante, propriedade privada. Contudo, as evidências se mostram muito mais fortes para a anterioridade do germe patriarcal à patrilocalidade, assim como à propriedade privada.

Há evidências de matrilocalidade, assim como de sociedades igualitárias tanto entre caçadores-coletores quanto no neolítico. Mas é necessário associar às evidências antropológicas a análise das condições climáticas, ecológicas e demográficas, para se compreender que o fator controlável, aquele que poderia de certa forma evitar a escassez de alimentos e de pessoas, deve ter sido o das capacidades reprodutivas das mulheres - o que, mais adiante, sujeitou-as mais facilmente às trocas, pela lealdade e conexão à progênie e/ou pelo subjugo do estupro. A hipótese de que a reificação feminina foi a primeira propriedade privada, o que levou à patrilocalidade, é suficientemente sólida para explicar, mais adiante, a estruturação da família e do estado patriarcal, inclusive a instauração da sociedade de classes, sendo esta a hipótese histórica fundamental de Lerner (1986).

Mesmo as evidências antropológicas mesopotâmicas que datam de 8000 a 5000 a.C mostram haver uma certa organização em classes. Com a acumulação de alimentos e a domesticação de animais, surgem elites e, por conseguinte, o militarismo começa a ser instaurado. Mais uma vez, a patrilocalidade é bastante oportuna, já que garantia a participação dos membros da família da esposa na organização e proteção das elites (LERNER, 1986). Mas quando Millett (2000) assevera classe como um dos pilares da política sexual, ela não está falando somente da estratificação de classes tradicional, mas de uma específica entre mulheres, que passam, nas civilizações mesopotâmicas, a serem divididas em esposa e concubina (até hoje uma distinção existente, embora bem menos institucionalizada). "Um dos maiores efeitos da classe dentro do patriarcado é colocar uma mulher contra a outra, no passado criando o vívido antagonismo entre prostituta e matrona e, no presente, entre a mulher de carreira e a dona de casa" (MILLETT, 2000, p. 38, tradução nossa). O concubinato, o casamento e a propriedade de terras, animais e excedentes demarcavam as primeiras classes que se estruturavam. As classes que subdividiam as mulheres, entretanto, eram diretamente dependentes das de seus maridos ou senhores; não havia nada que pudessem fazer caso o 
homem a quem, de uma forma ou de outra, pertenciam caísse na pobreza - o que ocorria com facilidade à época. E logo passou a depender, também, da boa vontade dos homens que, em caso de insatisfação com o trabalho sexual e reprodutivo provido pela esposa, poderiam delas se livrar, relegando-as à inexorável miséria (LERNER, 1986).

Voltando à questão de classe no sentido tradicional, o patriarcado esteve fortemente relacionado com a consolidação da sociedade de classes, além da criação de elites, mas também da exploração de mulheres, o primeiro modelo de escravização da história. Assim como o patriarcado, ela não é universal e, para ser implementada, exigiu o desenvolvimento de técnicas, a saber, a troca de uma morte violenta por uma vida de escravidão, a alienação natal, ou seja, a separação da família ou a não aceitação como membro da família de um dos seus progenitores, e a desonra generalizada da pessoa escravizada (PATTERSON, 1982). São técnicas que claramente correspondem àquelas resultantes de patrilocalidade, matrimônio e concubinato. Historiadores sabem há décadas que as mulheres foram os primeiros grupos na experiência da escravização. Contudo, eles em geral não foram capazes de associar esse fato histórico à edificação do patriarcado e de sua sociedade de classes, guiados que eram por seus valores androcêntricos (LERNER, 1986). É essencial enfatizar, aliás, que muito do que foi produzido sobre escravidão, das idades antigas ou modernas, tem sido influenciado não apenas por valores androcêntricos, mas raciais e classistas por parte dos historiadores, com explicações e justificativas de todos os tipos para o desenvolvimento deste que foi o mais hediondo dispositivo político humano.

A assimetria sexual, por si só um fato natural e sem valor inerente, tornou-se vantajosa quando homens e mulheres lutavam pela mais simples sobrevivência em contextos climáticos, ecológico e demográficos penosos. Isso levou à reificação, ou seja, à perspectiva das capacidades reprodutivas da mulher como um objeto passível de ser trocado. O que era estratégia de sobrevivência, e que por isso deve ter tido a concordância por parte das próprias mulheres, passou a ser fator essencial para a construção de privilégios por parte de homens, erigindo a primeira fundação de uma relação de poder entre os sexos. Assim, uma assimetria sexual levou a uma assimetria política, e dela nasceram o casamento e o concubinato (os primeiros experimentos inadvertidos de escravização), e a consolidação da propriedade privada (LERNER, 1986). É uma hipótese forte, por sua capacidade explicativa, além de sua adequação com evidências de sociedades patriarcais posteriores. Ou seja, com base nas mesmas evidências já conhecidas por historiadores e antropólogos, constrói-se uma hipótese bastante distinta, com certa exatidão e fertilidade. Os valores contextuais que servem para gerar o pano de fundo de ambas as análises são antagônicos, mas um deles pinta uma história muito mais complexa e sofisticada, mais próxima do que se compreende serem as interações entre grupos humanos, afastada de causas únicas.

Uma consequência de uma sociedade de classes é, naturalmente, o acesso ao capital, e o patriarcado, tendo estratificado as relações entre mulheres, também tem a economia como um pilar fundamental. Até hoje, a distribuição de riquezas entre os sexos no mundo é 
virtualmente inexistente ${ }^{8}$. Esse desequilíbrio é um dos primeiros produtos patriarcais, já que o proprietário dos animais e do excedente de alimentos era o chefe da família. Como os demais membros da família eram considerados propriedades do patriarca, filhas poderiam ser vendidas - em casamento ou submetidas à exploração sexual - seja para pagar o casamento do filho, seja para pagar dívidas. Em termos de dívidas, aliás, filhos e esposa poderiam ser escravizados como garantia por dívidas não pagas pelo chefe da família. Mais adiante, a desigualdade econômica se aprofunda com a estruturação da educação, da qual as mulheres foram ceifadas desde o início. Mesmo as mulheres de elite, nas civilizações antigas, medievais e até modernas, não tinham acesso ao mesmo tipo de educação endereçada aos homens (LERNER, 1993). No mundo, as mulheres só tiveram amplo acesso à educação superior a partir do final do século XIX. O apego à autoridade do homem era essencial para a sobrevivência da esposa, da concubina e da escrava, sendo reforçado pelo medo da fome e do estupro. "Nenhuma conexão de sororidade pode ser construída sob tais condições" (LERNER, 1986, p. 98, tradução nossa).

O que nos leva a outro pilar do patriarcado, historicamente oriundo da reificação das mulheres: a força. Millett (2000) referia-se à força na forma do estupro que, como se pode ver no estudo histórico de Lerner (1986), foi usado como técnica de aterrorização de mulheres cativas. Cabe ressaltar que no século XIX, milênios depois da consolidação do patriarcado, quando o tráfico de pessoas foi proibido, os dominadores passaram a usar o estupro de mulheres escravizadas como forma de manter a quantidade de mão de obra disponível para o trabalho nos campos. Como mostra Angela Davis (1981), as mulheres não eram vistas como mães, mas como trabalhadoras braçais (à semelhança de homens escravizados) e incubadoras, e tinham "valor de mercado" atrelado às suas capacidades de gestar.

Voltando às civilizações mesopotâmicas, quando as organizações sociais começaram a se sofisticar na forma de estado, questões de estupro ganham espaço inclusive nos primeiros códigos penais, como o assírio e o de Hamurabi. "O controle da sexualidade feminina, anteriormente deixado aos maridos ou chefes de família, agora passava a ser um assunto de regulação estatal" (LERNER, 1986, p. 121, tradução nossa). Neles, o estupro não era uma ofensa às mulheres, mas aos homens a quem pertenciam. Há uma variedade de imposições extremamente violentas, tanto aos estupradores quanto às estupradas e uma área cinzenta deixada pela identificação de estupro como adultério. Penalidades similares, como a morte por apedrejamento, ainda são consolidadas em várias partes do mundo.

O estupro teve papel fundamental, portanto, na construção das relações patriarcais e, depois, como parte ideológica dele. Não apenas Millett (2000), mas muitas feministas examinam o papel do fantasma da violência sexual para as alterações pelas quais o patriarcado teve que passar, de acordo com as fortes mudanças sociais do século XX. Millett

\footnotetext{
${ }^{8}$ Segundo o relatório da Oxfam International (2020), a riqueza combinada dos 22 homens mais ricos é maior que a riqueza combinada de todas as mulheres africanas. Se o trabalho não pago executado por mulheres acima de 15 anos fosse contabilizado na economia, ele valeria 10,8 trilhões de dólares (três vezes o tamanho da indústria da tecnologia).
} 
(2000) começa sua tese mostrando a violência sexual perpetrada como simples atos sexuais na perspectiva masculina, detalhadamente narradas em romances de grande sucesso do século $\mathrm{XX}$, e indica, já naquela época, a violência sexual normalizada pela pornografia, que vem sendo perscrutada pela socióloga Gail Dines (2010).

A hipótese de Lerner (1986) também é coerente com a paulatina queda dos mitos das deusas-mães, sendo substituídos pelas religiões patriarcais e monoteístas. De fato, mito $e$ religião são um pilar da política sexual, e para ambas as pensadoras, um dos artefatos mais sofisticados da organização patriarcal. Se a derrocada das mulheres tivesse ocorrido como consequência da patrilocalidade, certamente as religiões patriarcais teriam sido instauradas cinco milênios antes; o mesmo ocorreria caso a agricultura e a propriedade privada a tivessem provocado. Contudo, durante milênios, as religiões e mitos matriarcais, centrados fortemente na fertilidade e no parto, subsistiram mesmo nas sociedades patriarcais. Templos, mitos e profetisas mantinham um espaço em que a figura feminina tinha voz e importância. $\mathrm{O}$ desaparecimento lento, mas quase total, da simbologia do feminino como o responsável pela vida foi um marco do alcance de uma fase de grande sofisticação do patriarcado. O domínio simbólico agora também pertencia aos homens, com a narrativa de que a vida vem do patriarca, sendo a mulher apenas o meio de concretização de tal milagre, desconectado das percepções naturais da gestação e do nascimento. Cabe, enfim, enfatizar os papéis designados para homens e mulheres nas religiões greco-romanas e judaico-cristãs, sua assimetria sexual e política, e o desequilíbrio da culpa maior pelo mundo, tanto no mito da Caixa de Pandora, quanto no da Queda do Homem (LERNER, 1986; MILLETT, 2000).

Millett (2000) ainda discerne dois pilares da política sexual - o psicológico e o ideológico - cujas articulações com a hipótese do patriarcado histórico de Lerner (1986) ficam claras ao se compreender a edificação de todos os outros pilares. Millett (2000) reflete acerca do ego feminino que parece caracterizado por niilismo e auto sabotagem, consequência de ser construído por uma sociedade tão permeada de propagandas, leis, ciências e artes de valores factualmente misóginos. Muitas pesquisas têm sido feitas com mulheres em relação às suas opiniões sobre si mesmas e outras mulheres, mostrando uma inclinação feminina a dar preferência aos homens, seus trabalhos e atitudes, em detrimento de trabalhos e atitudes iguais executados por mulheres (MILLETT, 2000; SCHIEBINGER, 2001; NYE, 1995).

Lerner (1986) busca outro caminho, distinto da interpretação dada por Millet (2000) ao fator psicológico, por esta última ecoar a psicanálise ${ }^{9}$. Lerner sugere uma perspectiva psicológica sobre as evidências antropológicas, para o fato de os homens terem buscado uma organização de seus espaços exclusivos (que eles mantêm até os dias de hoje) e a milenar segregação a que submeteram as mulheres. Para ela, isso pode ter tido início ainda entre os primeiros homens. Os meninos não partiam para a caça junto com seus semelhantes, ficando

\footnotetext{
${ }^{9}$ Lerner não tece julgamentos de valor à psicanálise, mas enfatiza que as interpretações das evidências da história das mulheres devem ser construídas com a máxima independência de panos de fundo conceituais de perspectiva androcêntrica, com o que concordo.
} 
aos cuidados das mulheres e da criação de uma cultura feminina de trabalho, gestação, amamentação e maternagem - ou seja, seu relativo atraso na socialização masculina. Para eles, a figura feminina "tinha verdadeiramente o poder da vida e da morte. Não à toa, homens e mulheres, observando esse poder dramático e misterioso da fêmea, passaram a venerar deusas-mães" (LERNER, 1986, p. 40, tradução nossa).

Todavia, o argumento psicológico mais interessante que Lerner erige com base da história das mulheres é, de fato, sobre os efeitos de terem sido participantes inadvertidas, embora ativas, da criação de um sistema político que pouco a pouco tornou-se violento contra elas. A alienação da vida pública, da troca de conhecimentos e o desespero de ter vida e dignidade atreladas à boa vontade de seus senhores causaram uma grande dificuldade de expansão de visão de mundo; o impedimento do convívio com outras mulheres - e, de fato, a incentivada competição entre elas - coibiu-as de enxergar a aviltação que sofriam. Ademais, “a revogação do amor e a designação de mulheres pensantes como 'desviantes' foi historicamente um meio de desencorajar o trabalho intelectual das mulheres" (LERNER, 1986, p. 226-227, tradução nossa). E isso se dá até hoje, com as dificuldades que as mulheres têm de se libertar do ponto de vista patriarcal em suas vidas pessoais, profissionais e até acadêmicas.

Com tudo isso enfim, o patriarcado, para além de um sistema político, é também uma ideologia, e depende fortemente de boa parte da população feminina em sua aceitação. Simone de Beauvoir (1967) dizia que o opressor não seria tão forte se os oprimidos não fossem cúmplices da opressão; Hannah Arendt (1969) dizia que um sistema político existe não só pela força, mas pela conformação dos membros. E ele foi pernicioso o suficiente, ao distorcer fatos biológicos, criar mitologias e segregar mulheres, criando uma concepção de mundo tão sólida, que até hoje, mesmo em meios feministas, é demandada minuciosa vigilância axiológica. A história do patriarcado, gradativa, mas bem construída, fez com que a criação de consciência feminista demorasse anos para se estruturar (LERNER, 1993).

Nesta seção, quis mostrar o argumento de Lerner (1986) que, diante de evidências antropológicas e históricas, parece mais robusto em capacidade explicativa não apenas de eventos neolíticos, mas das etapas que procederam nos milênios posteriores, e que envolve a complexidade psicológica e ideológica que geralmente têm as relações humanas. Pensando em termos da filosofia da ciência de Longino (1990), pode-se ver, por exemplo, as críticas de natureza conceitual, sobretudo relativas aos pressupostos que sustentavam as primeiras explicações para o patriarcado. Sobre essa crítica conceitual, Lerner (1986) construiu uma visão histórica desse sistema político, incorporando ainda os conceitos de patrilocalidade e propriedade privada, reconhecidamente importantes na história da civilização. Apesar de sua robustez, essa hipótese histórica do patriarcado é geralmente desconhecida, mesmo em meios feministas, com persistentes preferências pelo argumento materialista-histórico de Engels. Isso ressalta questões de circulação de conhecimento acadêmico e igualdade de autoridade intelectual entre os propositores de teorias, mesmo que históricas. Naturalmente, é eco da 
ideologia patriarcal, que nos educa dentro de seus preceitos e nos previne de conhecer os conhecimentos erigidos por mulheres. Concordo com Lerner (1986) quando afirma que o conhecimento da história das mulheres pode ser um divisor de águas na forma como uma mulher se vê como ser histórico. E aqui, vou além: avanço o argumento da historiadora para evocar que a vigilância epistemológica e axiológica exigida pela análise das hipóteses sobre o patriarcado como conhecimentos sociais, sob pressupostos globais patriarcais ou feministas, pode ajudar a transitar por qualquer outra guerra de narrativas - inclusive aquelas que vivemos na atualidade e que (apenas) parecem distantes das patriarcais que aqui apresentei.

\section{Quanto de patriarcado tem na guerra de narrativas da atualidade?}

Vale a pena reiterar dois pontos essenciais em meu argumento até agora. Em primeiro lugar, de que compartilho da interpretação de que as relações entre os sexos são o sistema político mais longevo da humanidade, ao qual damos o nome de patriarcado. Compartilho desta posição por duas razões: ideológica e epistemológica. Ideologicamente, porque acredito que a luta contra a exploração humana é um valor social fundamental. Concordo com Longino (1990, p. 190, tradução nossa) quando diz que "[f]eminismo é muitas coisas para muitas pessoas, mas é no seu âmago, em parte, sobre a expansão da potencialidade humana”. Ademais, todas as mudanças que o patriarcado sofreu e, mais ainda, o fato de que as vozes das mulheres, apesar de tudo, conseguiram emergir dos milênios de silenciamento e obliteração, são evidência essencial de que ele não é universal e eterno. Assim, minha ideologia faz com que eu veja o mundo e os conhecimentos sob esse pressuposto global, usando o conceito de Longino (1990).

$\mathrm{O}$ que me leva à segunda razão, de natureza epistemológica. Compreender que as hipóteses científicas são construídas sobre evidências, mediadas por pressupostos globais e específicos, mostra que as várias interpretações dadas para a origem da "condição" feminina, apesar de trazerem elementos interessantes para a construção de uma ideia feminista, eram fortemente centralizadas no homem. Como as hipóteses são subdeterminadas pelas evidências, a crítica intersubjetiva é essencial para a detecção desses valores. A hipótese de Lerner (1986), além de dar uma explicação sólida para as evidências paleoantropológicas e históricas, consegue incorporar conceitos propostos por outras teorias (como propriedade privada e patrilocalidade), provê um quadro conceitual frutífero para interpretar evidências históricas de épocas posteriores e dialoga fortemente com os acontecimentos contemporâneos relativos às interações entre mulheres e homens, apontadas por Millett (2000). Além disso, propõe-se a revisão, não se pretendendo uma explicação universal, já que ela foca especificamente nas civilizações mesopotâmicas, egípcia e grega, pelos efeitos que tiveram na construção da visão política do ocidente, mas deixa aberta a análise para outros contextos.

Mesmo sabendo que esta é uma hipótese robusta e potencialmente mais objetiva, por ser baseada na crítica conceitual e na identificação de valores androcêntricos de outras teorias, 
ela é uma narrativa, uma maneira de interpretar o mundo, e esse é o segundo ponto que quero reiterar. O interessante é que ela contesta consistentemente a narrativa hegemônica milenar da superioridade e dominação masculina. No campo do patriarcado, com a supressão da voz e da importância das mulheres para a civilização, o termo guerra de narrativas só pode ser considerado a partir do século XIX, e, a julgar pelo desconhecimento de várias feministas atuais do que foi produzido nas ondas anteriores, atrevo-me a dizer que ele ainda consegue silenciar as narrativas feministas. Faz parte do DNA patriarcal, por sua inigualável capacidade de segregar e rivalizar mulheres. E ele faz isso sofisticando sua narrativa, muitas vezes com o apoio da ciência. Sendo todos, inclusive as mulheres, socializadas em um mundo patriarcal, é demandada, inclusive de feministas, permanente vigilância epistemológica e axiológica para detectar os valores androcêntricos e misóginos que habitam narrativas supostamente neutras. E a pretensão de neutralidade é típica de uma narrativa que se pretende autoritária.

A versão dos homens da história, legitimada como a "verdade universal", apresentou as mulheres como marginais à civilização e como vítimas de processo histórico. Ser apresentada assim e acreditar nisso é quase pior que ser inteiramente esquecida. O retrato é falso, em ambos os casos, como agora sabemos, mas o progresso das mulheres através da história foi marcado pela luta contra essa distorção incapacitante (LERNER, 1986, p. 223, tradução nossa).

Se fosse necessário resumir o patriarcado em um único valor, seria controle. $\mathrm{O}$ controle dos corpos femininos, primeiramente em virtude do cenário climático e ecológico, passando pela manutenção de paz entre tribos, até a construção de um sistema político de classes. Considerando que a ideologia patriarcal está na semente da propriedade privada e da estrutura política (no sentido tradicional) da atualidade, passa-se a compreender quão permeada pelo valor do controle é esta última. $\mathrm{O}$ assentimento a uma relação de poder pode demandar a violência ou a inculcação a uma ideologia. No patriarcado - e nos sistemas políticos tradicionais da atualidade, porque dele são oriundos - essa socialização se faz por meio da construção de narrativas, que não raro se blindam à intersubjetividade e, portanto, à busca por uma objetividade. Distorcem fatos e refutações, com o controle das mentes, dos corpos e das hierarquias atuais como objetivo final.

Minha preferência pela análise da objetividade e da intersubjetividade, muito mais que da verdade, se deu em virtude das sofisticações filosóficas que o termo verdade demanda e minha visão de que compreender a ciência como conhecimento social é bastante fértil para analisar guerras de narrativas. Voltando a usar o termo verdade - em razão da análise do fenômeno da pós-verdade -, eu o farei usando o sentido mais comum e amplo da palavra, algo similar ao que Hannah Arendt (2011) chamou de verdade de fato ${ }^{10}$ - a verdade coletiva, que

\footnotetext{
${ }^{10}$ Arendt (2011) diferencia verdade de fato de verdade racional. Esta última seria o domínio dos axiomas matemáticos e da ciência. Considerando minha preferência pela filosofia da ciência como conhecimento social, entendo que essa diferenciação não é tão clara assim, sobretudo em relação às "verdades" da ciência. Mas essa discussão, que deve se dar no domínio da filosofia da ciência, é marginal nesta seção do trabalho; dado que falo
} 
associa fatos estabelecidos e consensuais. Mas voltarei à questão da objetividade oportunamente.

É interessante ressaltar que o fenômeno de pós-verdade atual é marcado pelo que se entende pela secundarização da verdade (SANTAELLA, 2018). Mas essa característica só pode ser atribuída desde uma perspectiva externa à bolha que gera a distorção dos fatos. Àqueles nela inseridos, a verdade pode ser a da bolha.

Os seres humanos têm a tendência de confiar em seus primeiros instintos. Parte da psicologia dá resposta evolutiva a esse ímpeto, pois ele pode ter sido essencial para a sobrevivência dos primeiros hominídeos. Se somos descendentes daqueles que sobreviveram a condições inóspitas, que o fizeram por seguir suas percepções, somos herdeiros de um "modo sobrevivente" de interagir com os fenômenos da natureza (PILATI, 2018). Contudo, os objetos de investigação acadêmica - sejam fenômenos naturais, sejam fenômenos sociais não são autoevidentes aos instintos e aos sentidos. Demandam do investigador uma variedade de questionamentos, dúvidas, pensamentos divergentes. Mais ainda, conhecer fenômenos de tal sofisticação exige a compreensão de que construir conhecimento é ação coletiva, mediada muito mais pela crítica que pela ampla concordância (LONGINO, 1990). Assim, relativamente a assuntos públicos que demandam deslocamentos entre conhecimentos variados, inclusive acadêmicos, é natural que as pessoas tenham a tendência instintiva de buscar a narrativa que não desafie suas expectativas e convicções, evitando aquelas que demandem o desconforto da desconfiança.

A importância emocional que é dada à sensação de pertencimento a um grupo também não pode ser negligenciada. Isso pode influenciar indivíduos a contestar fatos consensuais e a compartilhar de novas verdades, de reinterpretação dos fatos. Há também aqueles que, mesmo entendendo a distorção dos fatos, podem induzir o falso testemunho. Mais importantemente, a verdade dos fatos só é viva enquanto as pessoas dela compartilham, pública ou privadamente. Arendt (2011) enfatiza um ponto gritante para quem lida com as "verdades" produzidas nos recônditos das redes sociais: parece cada vez mais fácil rejeitar a verdade de fato como outra opinião. Por isso ela pode ser frágil, por isso tem natureza política.

É possível ver que a opinião que vira uma verdade dentro de uma bolha ou que, inadvertidamente ou não, distorce os fatos, é característica de uma variedade de acontecimentos políticos. A universalização do determinismo biológico, por exemplo, fez com que se visse como verdadeira, por muitas eras, a inferioridade feminina. Mesmo depois dos primeiros levantes feministas, novas narrativas adaptaram-se de maneira a salvaguardar a centralidade masculina. A divisão das mulheres em classes fez e continua fazendo com que muitas delas subscrevessem a essa ideologia, tratando os homens como superiores e as outras mulheres como indignas, às vezes ingenuamente, muitas vezes como forma de manutenção de

agora de política e pós-verdade, entendo que o termo possa ser usado um pouco mais livremente e que as reflexões da pensadora sejam mais que pertinentes. 
suas classes. Tomando um exemplo do momento histórico que vivemos, a questão da hidroxicloroquina como terapia para a Covid-19 teve públicos diferentes em suas bolhas: os que têm a opinião de que esse é um tratamento que pode curar, por acreditarem em evidências anedóticas, assim como os que aproveitaram o momento para cooptar a narrativa e alterá-la com fins políticos.

Essas redes humanas que preservam e buscam sofisticar e corroborar a opinião, chamadas de bolhas, sempre existiram. Também é evidente, de um ponto de vista evolucionário, que as pessoas busquem confraternizar com os que pensam igual. Conforme Lerner (1986), os espaços exclusivos masculinos podem ter tido início na necessidade masculina de criar uma narrativa sua, após passar anos convivendo, enquanto crianças, na "bolha feminina". Mas não seria exagero atribuir o despertar do potencial político dessas instâncias ao seu uso para a criação de narrativas que distorciam fatos amplamente evidentes, como foi o caso dos cultos às deusas-mães, que tinham tal status em virtude da gestação, do parto e da amamentação, mas cuja supressão culminou na estruturação das religiões monoteístas patriarcais, em que uma divindade à semelhança do homem é responsável pela vida, fazendo da mulher mero meio de concretização. A blindagem à crítica intersubjetiva foi o menor dos problemas para o patriarcado, já que a segregação das mulheres impediu que outras narrativas centradas nelas mesmas fossem sequer construídas e fez com que muitas se conformassem e inclusive abraçassem a ideologia patriarcal, aniquilando as outras narrativas matriarcais.

Resta claro o poder de uma bolha: com os membros certos, pode silenciar narrativas concorrentes e instituir uma verdade de pretensões universais, em uma ofensiva pelo controle. E isso é bastante emblemático no momento atual, em que essas bolhas servem para direcionar eleições e políticas públicas de saúde e ganham força espetacular a partir dos algoritmos das redes sociais, que oferecem ao usuário um recorte do mundo que tenha total associação com as suas preferências de navegação. Esses algoritmos, agora cooptados por inteligentes cientistas de dados, têm promovido um interessante e assustador novo fenômeno: o da centrifugação das opiniões políticas. Empoli (2019), analisa o tipo de propaganda política a que estamos sujeitos desde a escalada vertiginosa das redes sociais para enfatizar que, se anteriormente, na política tradicional, os meios de comunicação como a televisão, o cinema e a rádio exigiam dos políticos (e politiqueiros) mensagens massificadas abrandadas (que ele chama de política centrípeta), a individualização de exposição à propaganda, permitida pelas redes sociais, tem radicalizado os posicionamentos políticos de grande parte da população.

Nesta tendência de política centrífuga, cabe pensar, a convite de Empoli (2019), sobre o que substituirá os atuais populistas que vêm sequestrando os fatos em benefício próprio. No que depender do tipo de propaganda permitido pelas redes sociais, não é exagero dizer que a mais patriarcal das ideologias políticas está tomando forma mais uma vez. O fascismo e sua invocação a um passado mítico, centralizado na família patriarcal, nos grandes êxitos de homens do passado; o fascismo, que demanda claras hierarquias sexuais, sociais, 
raciais e étnicas; o fascismo, que se entende responsável por uma nostálgica sociedade apogeica, onde homens e mulheres tinham seus papéis bem definidos, está cada vez mais presente nas opiniões inescrupulosamente tornadas públicas pelas mais variadas pessoas comuns (STANLEY, 2018).

\section{O que a ciência e a educação científica têm a ver com os tempos de pós-verdade?}

Hormônios neurotransmissores são resultantes dos nossos milênios de evolução e os principais responsáveis por nossas sensações de conforto, euforia, obstinação, entre outras. Serotonina, adrenalina, endorfina, oxitocina e dopamina, por exemplo, tiveram funções essenciais para a sobrevivência de nossos ascendentes e continuam sendo produzidas em nossos organismos, a depender dos estímulos a que somos submetidos. Ocorre que um destes, a dopamina, vem sendo bastante estudada, não apenas por fisiologistas, mas também pela indústria alimentícia e pelos gigantes da tecnologia. É um neurotransmissor encarregado de passar uma mensagem de prazer imediato e recompensa. Contudo, comportamentos liberadores de dopamina, quando em excesso, têm o efeito dessensibilizar o sistema dopaminérgico, impelindo a busca por novos comportamentos capazes de liberar ainda mais este hormônio. Por isso, o interesse que gera em determinadas indústrias: produtos alimentícios à base de açúcar, maratonas de séries e curtidas e respostagens nas redes sociais são alguns dos hábitos cotidianos da atualidade que geram a montanha-russa de alegria e letargia causada pelos picos e quedas de dopamina. Um dos fundadores do Facebook foi expressivo em relação ao seu conhecimento do potencial da dopamina na manutenção dos usuários das redes sociais (EMPOLI, 2019).

Grandes bilionários, portanto, devem suas fortunas ao hackeamento de inclinações psicológicas e fisiológicas humanas. A ciência é bem conhecida destes gigantes e usada como objetivo de manter-nos engajados nas redes sociais. Então, é irônico - para nós usuários, ao menos - que o conhecimento da ciência da fisiologia seja usado para a criação de redes em que teorias da conspiração anticientíficas se disseminam seis vezes mais rápído que teorias científicas de amplo acordo (EMPOLI, 20019). Ao defender a ciência como conhecimento social, argumentei pela importância lógica do ceticismo e da crítica intersubjetiva, algo que é feito com certo sucesso na comunidade científica. Grupos conspiracionistas, por outro lado, não compartilham deste tipo de ceticismo, mas rechaçam sumariamente a ciência sólida, motivados por uma forte sensação de frustração com sua instrumentalização pelo sistema político. Não à toa, têm sido os alvos mais claros e efetivos dos grandes cientistas de dados geralmente físicos de formação, diga-se de passagem - seja para a simples manutenção do tempo de engajamento nas redes, seja para a consequente manipulação política.

Uma frustração bastante particular que acomete uma série desses grupos negacionistas é a do tipo sexual - como diz Empoli (2019), a manipulação dopaminérgica gerida pelas redes sociais a todos transforma em uma espécie de adolescente, com alegrias e 
raivas à flor da pele. Se as inquietações de todo o tipo têm movido eleições, políticas públicas de saúde, debates democráticos e até o acesso à educação, as frustrações de natureza sexual têm saído dos guetos dos fóruns da internet e contagiado opiniões tornadas públicas descaradamente. Advoga-se sem qualquer embaraço a hierarquização dos variados grupos sociais. Também sem acanhamento, quem começa a navegar a maré anticientífica e antidemocrática gerada pelo oceano dos altos e baixos hormonais da população é ideologia fascista, que nada mais é que a epítome do patriarcado. Portanto, são a democratização da comunicação e a ciência, na forma dos cientistas de dados e da manipulação psicológica e hormonal, que estão nos fundamentos de um período histórico em que grupos ensaiam demolir justamente a ciência e a democracia (STANLEY, 2019).

Diz um conto de H. C. Andersen que dois golpistas chegam a um império e logo conseguem chegar ao círculo do imperador, proclamando-se tecelões e alfaiates. Propõem-se a fazer uma roupa para ele, com um tecido tão especial que seria invisível àqueles incapazes de exercer suas funções, e também aos tolos e presunçosos. Recebem o material e o pagamento adiantado por parte do imperador que, além de prezar vestir-se impecavelmente, valorizou a concepção de poder detectar, entre seus súditos, aqueles capazes e incapazes de realizar seus trabalhos. Por dias, os vigaristas fingem preparar as novas roupas; o imperador pede que alguns dos que trabalham para ele vejam como está a produção. Sem conseguirem vê-lo, mas com medo de serem considerados incapazes para seus postos, os funcionários detalhadamente reportam ao imperador a beleza do traje. Quando pronto, o imperador vai vêlo, decidido a usá-lo em procissão com seus súditos. Não o vê, mas não poderia transparecer. Todos a sua volta o veem, menos ele, e ele não quer ser visto como inapropriado para a sua função de imperador. Elogia o traje e, ao vesti-lo, é muito enaltecido por todos a sua volta pela beleza inigualável. Parte para a procissão; lá, uma criança exclama que o imperador está nu. O imperador e seus consortes se mantêm impassíveis, enquanto o povo começa a gritar e apontar a nudez do monarca. O imperador continua a procissão, pois as palavras do povo, esse grupo de tolos, expressavam a verdade.

A anedota das novas roupas do imperador ilustra interessantemente as questões acerca de construções de narrativas que perpassaram este trabalho: o medo, o poder, a necessidade de pertencimento a um grupo, as emoções e vaidades. Culmina com o rei construindo para si uma nova verdade - e a reação da plebe é expressão máxima disso. A reinterpretação dos fatos dentro de um quadro de pressupostos distinto daquele do povo garante ao rei que sua roupa é, de fato, mágica. Ele não a vê, mas isso já não tem mais qualquer significância.

Adicione-se ao conto uma analogia, construída por Lerner (1986): o mundo é uma peça de teatro em que homens e mulheres têm papéis igualmente importantes. Não é possível história sem ambos. Entretanto, os homens controlam não apenas seus papéis, mas também o palco, o cenário, os adereços, o roteiro e a direção. Ao longo da história, as mulheres puderam apenas interpretar seus papéis, que foram escritos por homens. Demonstraram muitas vezes a 
competência para papéis tipicamente masculinos. Com o tempo, demandaram fazer parte da produção, e algumas puderam, desde que tivessem passado por uma seleção feita com critérios masculinos. Compreendiam estar ganhando igualdade, enquanto estavam sendo conformadas dentro dos padrões patriarcais. Por muito tempo, sem ver outra saída, as mulheres aplaudiram o traje especial e mágico do imperador. Mas, se o objetivo das mulheres é o de poder escrever e produzir seus próprios papéis e co-autorar essa grande peça de teatro, isso só pode ser feito se o contraditório e a intersubjetividade forem ações implacáveis.

O que as mulheres precisam fazer, o que as feministas agora fazem, é apontar para o palco, seus cenários, seus adereços, seus diretores e seus roteiristas, como fez a criança no conto de fadas que descobriu que o imperador estava nu, e dizer que a desigualdade básica que existe entre nós faz parte dessa estrutura. E então, elas devem derrubá-la (LERNER, 1986, p. 13, tradução nossa).

É lícito e inescapável que as pessoas tenham opiniões divergentes sobre os infinitos assuntos que tocam suas vidas. Entretanto, o aliciamento dessas opiniões, geralmente por meio de apelos emocionais e psicológicos, para fins políticos, busca de fato o controle desse e de outros grupos de pessoas. Diferentemente do privilégio do patriarcado, que se fez tão hegemônico a ponto de passar milênios sem que sua nudez fosse apontada, as bolhas da atualidade, por mais fechadas que sejam, não se fazem suficientemente herméticas. Prova disso é a própria existência de uma guerra de narrativas, das polarizações e dos acirramentos de ânimos testemunhados por esses tempos. A partir da história das mulheres, considero otimistamente que boa parte das pessoas que compartilham de "verdades" distorcidas, não o fazem por razões vis. Fazem-no pela instintiva busca do viés da confirmação, pelos estímulos hormonais recebidos das mídias digitais, pelo sentimento de pertencimento, ou por ignorar a multiplicidade de fatores que nuançam uma narrativa. Possivelmente, suspeito que gostariam de entender que podem estar fazendo um desserviço a si mesmas e que estão sendo fisiológica e politicamente manipuladas. É isso, afinal, o que me ensinou a história das mulheres. A vontade de pensar, de agregar a complexidade humana às representações da realidade são tão pulsantes que sobreviveram ao patriarcado e à ciência patriarcal. Nenhum instinto pelo viés da confirmação foi forte o suficiente para calar as vozes das mulheres contra o mais perene tirano da história humana. Portanto, é urgente refletir: o que fazer para desnudar esses (ainda pequenos) déspotas da atualidade?

A ciência e a educação sempre tiveram papel dual quando pensamos em política. Ambas foram usadas para a manutenção de narrativas que se pretendiam hegemônicas. Até hoje, em algumas bolhas, algum aspecto do imaginário científico (e, às vezes, até ciência consagrada por periódicos), distorcido ou não, é usado para a corroboração do ponto de vista compartilhado. Terraplanistas pensam colher evidências a todo tempo, tanto da lógica, quanto, por exemplo, da análise de rotas de aviões pela internet. O movimento anti-vacina baseia-se em um artigo publicado na The Lancet (uma das mais prestigiosas revistas médicas), em evidências anedóticas e no direito de integridade corporal. Os defensores da 
hidroxicloroquina como terapia para a Covid-19 baseiam-se em uma divulgação pré-print de um estudo de um renomado pesquisador francês e, também, em evidências anedóticas.

O que falta à compreensão generalizada é que a ciência não é composta por estudos ou opiniões de cientistas individuais, mas - em condições ideais - um processo bastante meticuloso de revisão, replicação e crítica. Há também a clara dificuldade de compreender que evidências anedóticas não podem ser evidências científicas. Elas podem vir a ser, mas precisam ser tratadas antes disso - é preciso ter certeza de quais valores contextuais influenciaram um determinado fato a se transformar em evidência. Assim como a pedra lascada não é evidência de que apenas os homens caçavam, e por isso de que são superiores às mulheres, uma pessoa que se cura de Covid-19 - que tem uma taxa de sobrevivência de mais de $90 \%$ - não pode garantir que o tenha feito em virtude da terapia com hidroxicloroquina. A mediação entre fatos e evidências, em ambos os casos, foi feita com base em suposições que estão longe de potencializar sua objetividade.

Esse é o tipo de conhecimento que, para ser ensinado, demanda uma educação científica muito diferente da praticada. Afinal, como é ensinada, a ciência a todos parece autoritária e representativa de fenômenos muitas vezes ininteligíveis, diferentemente da maneira como é e deveria ser feita. Naturalmente, isso é resquício histórico sobre o que, como sociedade, objetivamos com a educação. $\mathrm{Na}$ forma de direito fundamental e massivamente acessível, ela é um fenômeno relativamente recente, mais ainda que a própria ciência moderna. E enquanto seu acesso passava a ser democratizado, seus métodos passavam longe de democráticos. Preocupações de natureza psicológica e emancipatória só começaram a ocupar amplamente os investigadores da educação a partir da segunda metade de século XX. Por muito tempo, a educação serviu a interesses políticos e econômicos, na formação de mão de obra minimamente qualificada. Nela, vestígios patriarcais podem ser encontrados até hoje, na maneira de organizar uma sala, na interação com figuras autoritárias de professores e gestores, no conhecimento imposto, na percepção do aluno como tábula rasa e até na arquitetura escolar - porque muitas vezes na escola ainda reina o valor do controle. E apesar de esses ambientes terem sido construídos com o intuito de inculcar os cidadãos nas ideologias controladoras da nossa história, as escolas têm a potencialidade de fazer florescer a chama da crítica intersubjetiva, o espírito cético, a democracia e a solidariedade.

As grandes dificuldades de implementar mudanças paradigmáticas em educação e educação científica se dão porque a educação tem esse palpável papel político, e isso é fato bastante conhecido dos educadores da atualidade, tendo sido delineado tão minuciosamente pelo corpo da obra de Paulo Freire. Não à toa, defensores de movimentos como escola sem partido demandam uma "educação neutra", talvez se referindo a um tempo em que se buscava explicitamente educar para o trabalho. Coerentemente, a "neutralidade" é pretensão de ideologias autoritárias (DUNKER, 2018). Cabe aos educadores compreender isso: a mera transmissão de conhecimentos tidos como científicos não é ensinar ciência, tanto pelo fato de sobre ela nada falar, quanto pelo fato de que quase tudo nela muda e se adapta, como 
simbólica que é da curiosidade do espírito humano. A imposição autoritária de um conhecimento acabado e imune à crítica e ao escrutínio histórico e filosófico não é uma maneira de fugir de ideologias penetrantes, na medida em que fugir de uma ideologia é assentir a outra, possivelmente mais totalitária.

Logicamente que o educador em ciências não poderá deixar de ensinar os conteúdos da ciência para ensinar sua filosofia. Mas, ao convidar os alunos a compreender e identificar os juízos de valor que muitas vezes fizeram os cientistas, eles os levam a perscrutar hipóteses, evidências e articulações teóricas diferentes, além de exercer a crítica. Nossos tempos de pósverdade podem estar mostrando que certas apropriações solidamente baseadas nos conceitos e teorias da história da ciência devem ser mais profícuas do que a imposição autoritária do conhecimento. Quando falo disso, falo de resoluções intermináveis de exercícios e memorizações de classificações pouco significantes àquela maioria que não seguirá uma carreira científica ou tecnológica, mas viverá em um mundo científico e tecnológico. Não seriam as rápidas valorizações de ideologias autoritárias e anticientíficas, por parte do alunado, um efeito de que nossa educação científica tem feito pouco por suas autonomias de pensamento?

Neste trabalho, trabalhei sexo como uma categoria política. Mesmo compreendendo o patriarcado como o mais antigo sistema político, não ignoro a onipresença também dos sistemas de raça e classe que provocam relações de dominação e subjugação. Analisando a história do patriarcado, fica claro que um efeito patriarcal foi transformar mulheres em dominadoras de outras mulheres, com a estratificação de classes e posteriormente, de raça. Foi o trunfo patriarcal, ao qual nós não podemos mais nos submeter; é uma atitude patriarcal a inação aos sistemas de opressão que existem e mantemos dentro de grupos de mulheres, inclusive feministas. Para isso, a vigilância axiológica permanente é fundamental. Quão patriarcais somos quando deixamos que mulheres não-brancas sejam silenciadas? Quão patriarcais somos quando exploramos o trabalho de mulheres de outras classes sociais? Quão patriarcais somos quando não desenvolvemos redes de proteção às mulheres que não têm as facilidades reprodutivas e sexuais que algumas de nós temos? Quão patriarcais somos quando reproduzimos violência doméstica em nossos filhos, na forma de coerção, autoritarismo e violência física? Quão patriarcais somos quando, como mães e professoras, queremos construir nossa autoridade de forma autoritária? Quão patriarcais somos quando não demandamos uma nova educação, que acolha e prepare as mentes para os dissensos, consensos e construções políticas dos quais nossos alunos participarão?

Freire (1996) mantém viva a dimensão política da educação, quando evidencia o espírito ético essencial a um professor que busque uma pedagogia da autonomia. Seu foco é a luta de classes, claro, mas o que ele oferece como perspectiva de educação para a autonomia é essencialmente anti-patriarcal - como não poderia deixar de ser, dentro do quadro teórico que aqui apresentei. $\mathrm{O}$ reconhecimento do condicionamento não pode ser compreendido como fatalista, mas como marca da ação. O futuro pode ser problemático, mas não é inexorável. 
Uma educação para o futuro exige o diálogo com os alunos para a dialética do mundo. Como diz Arendt (2011) a marca da liberdade humana é nossa capacidade de mentir, mais do que a de dizer a verdade. Não há escapatória das distorções, mas a educação poderia ajudar a preparar os alunos, que hoje, desprevenidamente, aceitam que o lindo traje do imperador é a verdade, mesmo que isso não mude o estado de dominação que o imperador exerce sobre eles. Enunciar e anunciar a nudez do imperador é preciso e tem espaço na sala de aula de ciências.

Desnudar o imperador passa, necessariamente, pela abordagem honesta da história da ciência, da sociedade, da política; da história da verdade e da mentira, enfim, como provoca Albuquerque Jr. (2018, pos. 1487/1931)

Quem disse que uma história da verdade é mais importante que uma história da mentira e da tolice? Talvez se as fizéssemos, descobriríamos que elas são muito mais decisivas na vida social do que o papel e lugar que atribuímos às verdades. [...] Interessaria, portanto, aos historiadores não apenas fazer uma história da verdade, mas historiar as regras e gestos que separam o verdadeiro do falso, o verdadeiro do mentiroso, o verdadeiro do enganador, o verdadeiro do tolo e do imbecil [...] estudar como se atenta, todo dia, nas redes sociais, contra a inteligência, seria um bom exercicio para aqueles que queiram compreender o nosso tempo e as verdades de que é capaz.

Para isso, o permanente (embora imperfeito) hábito tácito na ciência da busca da objetividade como mitigação das intrusões subjetivas no conhecimento pode e deve ser uma prática educacional e de nossas vidas cotidianas. E assim finalizando, adapto uma frase icônica de Gloria Steinem ${ }^{11}$ e afirmo: a objetividade liberta, mas primeiro enraivece. Desnudar o rei não significa ganhar uma guerra de narrativas, pois como vimos, narrativas hegêmonicas são monopólios de regimes autoritários, dos quais, ideologicamente, compreendo que devemos manter distância. Precisamos lutar para que elas continuem existindo, mas idealmente mais sofisticadas, hospitaleiras ao dissenso, dotadas de consciência política, honestidade intelectual e, especialmente, de autocrítica.

\section{Referências bibliográficas}

ALBUQUERQUE JÚNIOR, D. M. Ser um historiador de verdades: apontamentos sobre uma aporia insuperável do discurso historiográfico. In: RIBEIRO, R.; PINHEIRO, H. (Orgs). Jornalismo em tempos de pós-verdade. ed. Kindle. Fortaleza: Dummar, 2018.

ARENDT, H. Speculations on violence. The New York Review of Books, v. XII, n. 4, 1969.

\footnotetext{
11 "Truth will set you free, bur first it will piss you off", virou livro com subtítulo "Thoughts on live, love, and rebellion" em 2019.
} 
ARENDT, H. Verdade e Política (1967). In: ARENDT, H. Entre o Passado e o Futuro. ed. Kindle. São Paulo: Perspectiva, 2011.

BEAUVOIR, S. O Segundo Sexo II: A experiência vivida. São Paulo: Difusão Europeia do Livro, 1967.

DAVIS, A. Women, race \& class. Nova Yorl: Random House, 1981.

DINES, G. Pornland: how porn has hijacked our sexuality. Boston: Beacon Press, 2010.

DUNKER, C. I. L. Em tempos de pós-verdade, o que significa ideologia. In: RIBEIRO, R.; PINHEIRO, H. (Orgs). ed. Kindle. Jornalismo em tempos de pós-verdade. Fortaleza: Dummar, 2018.

EMPOLI, G. D. Os engenheiros do caos. São Paulo: Vestígio, 2019.

ENGELS, F. A origem da família, da propriedade privada e do estado. São Paulo: Boitempo, 2019.

HACKING, I. Representar e Intervir: tópicos introdutórios de filosofia da ciência natural. Rio de Janeiro: EdUERJ, 2012.

KUHN, T. S. A Estrutura das Revoluções Científicas. São Paulo: Perspectiva, 2006.

KUHN, T. S. Objectividade, juízos de valor e escolha teórica. In: KUHN, T. S. A Tensão Essencial. Lisboa: Edições 70, 2009. p. 363.

LAUDAN, L. Science and Values: the aims of Science and their role in scientific debate. Berkeley, Los Angeles: University of California Press, 1984.

LERNER, G. The creation of patriarchy. Nova York, Oxford: Oxford University Press, 1986.

LERNER, G. The creation of feminist consciousness: from de middle ages to eighteenseventy. Nova York, Oxford: Oxford University Press, 1993.

LÉVI-STRAUSS, C. As estruturas elementares do parentesco. Petrópolis: Vozes, 1982. 
LONGINO, H. E. Science as social knowledge: values and objectivity in scientific inquiry. Princeton: Princeton University Press, 1990.

MILLETT, K. Sexual politics. Nova York: Simon\&Schuster, 2000.

NYE, A. Teoria feminista e as filosofias do homem. Rio de Janeiro: Editora Rosa dos Tempos, 1995.

OFFEN, K. M. European Feminisms, 1700-1950: a political history. Stanford; Stanford University Press, 2000.

OXFAM INTERNATIONAL. Time to care: unpaid and underpaid care work and the global inequality crisis. Oxford: Oxfam GB, 2020.

PATTERSON, O. Slavery and social death: a comparative study. Cambridge: Harvard University Press, 1982.

PILATI, R. Ciência e pseudociência: por que acreditamos naquilo em que queremos acreditar. São Paulo: Contexto, 2018.

SAINI, A. Inferior: The True Power of Women and the Science that Shows It. ed. Kindle. Londres: 4th Estate, 2017.

SANTAELlA, L. A Pós-Verdade é verdadeira ou falsa? Barueri: Estação das Letras e Cores, 2018.

SCHIENBINGER, L. O feminismo mudou a ciência? Bauru: EDUSC, 2001.

STANLEY, J. Como funciona o fascismo: A política do "nós" e "eles". Porto Alegre: L\&PM, 2018. 